\title{
Trends in WAO-intrede door RSI
}

\author{
S.G. van den Heuvel • B.M. Blatter
}

\begin{abstract}
Gegevens van UWV zijn geanalyseerd met als doel het verloop van WAO-intrede door RSI te beschrijven in de periode $1998 \mathrm{t} / \mathrm{m}$ 2004. Hieruit blijkt dat een stijging van WAO-intrede door RSI in de jaren $1998 \mathrm{t} / \mathrm{m}$ 2001 is opgetreden, gevolgd door een daling in $2002 \mathrm{t} / \mathrm{m}$ 2004. Bij vrouwen, bij personen in de leeftijdsgroep van 45-55 jaar en bij werknemers in de industrie en bouw komt de meeste WAO-intrede door RSI voor. Hoewel de meeste aandacht over het algemeen uitgaat naar sectoren waar veel computerwerk wordt verricht, zijn dit niet de sectoren met de hoogste incidentie van WAO-intrede door RSI. Wanneer zowel rekening wordt gehouden met het aantal werknemers als met de incidentie binnen een sector zouden maatregelen binnen uitzendbedrijven, reinigingsbedrijven en bouwbedrijven het meest effectief zijn om de totale WAO-intrede door RSI te doen dalen.
\end{abstract}

Keywords rsi · wao-instroom · arbeidsongeschiktheid . risicosectoren

RSI-klachten komen nog steeds veel voor in de Nederlandse beroepsbevolking. Recente cijfers uit een vragenlijstonderzoek bij werknemers en zelfstandigen (TNO Arbeidssituatie Survey, TAS) wijzen uit dat de prevalentie van RSI-klachten tussen 2000 en 2002 gestegen is van $26 \%$ naar $28 \%{ }^{1}$ RSI-klachten zijn in het genoemde onderzoek gedefinieerd als 'de afgelopen 12 maanden

S.G. van den Heuvel $(\bowtie)$

Drs. S.G. van den Heuvel en dr. B.M. Blatter zijn beiden werkzaam bij TNO Arbeid, Hoofddorp en Body@Work, Onderzoekscentrum Bewegen, Arbeid en Gezondheid TNO VUmc, AmsterdamCorrespondentieadres: TNO Arbeid, t.a.v. S.G. van den Heuvel, Postbus 718, 2130 AS Hoofddorp.

E-mail: S.vdHeuvel@arbeid.tno.nl regelmatig of langdurig last van nek, schouders, armen/ ellebogen of polsen/handen, waarbij de klachten geheel of gedeeltelijk door het werk veroorzaakt zijn'.

Het is niet bekend hoeveel van de werknemers met klachten op den duur chronische klachten krijgen. Uit onderzoek met gegevens van het Rijksinstituut voor Volksgezondheid en Milieu (RIVM), blijkt dat 8\% van de werkzame bevolking in 1998 verzuimde door klachten van nek, schouders, arm, elleboog of pols en hand. ${ }^{2}$ Een klein gedeelte wordt langdurig arbeidsongeschikt en komt in de WAO terecht. Uit cijfers van het toenmalige Landelijk Instituut Sociale Verzekeringen (Lisv) blijkt dat in 1998 het percentage werknemers dat door RSI in de WAO terecht kwam, $0,01 \%$ was bij een nauwe definitie van RSI en $0,04 \%$ en $0,05 \%$ bij iets ruimere definities van $\mathrm{RSI}^{2}$

Vanaf 1998 is de belangstelling voor RSI toegenomen. Binnen bedrijven is er meer aandacht voor en worden er ook maatregelen genomen. Zo zijn er inmiddels in een aantal sectoren afspraken gemaakt tussen werkgevers, werknemers en de overheid in de zogenoemde arboconvenanten. Verder is er een groeiende markt voor antiRSI-producten zoals pauzesoftware, alternatieve muizen en muismatjes en biofeedbacksystemen. Ook is er inmiddels meer bekend over risicofactoren. Behalve de fysieke belasting op het werk, zoals langdurig in dezelfde houding zitten en het uitvoeren van repeterende bewegingen, blijken ook psychosociale factoren van belang voor de ontwikkeling van RSI. ${ }^{3,4}$ Tenslotte zullen verzekeringsartsen meer aandacht hebben voor het probleem en vaker aan RSI denken bij het vaststellen van de CAS-code. Niet in alle sectoren is het risico op RSI even groot. In bedrijven waar veel repeterend werk wordt verricht en in bedrijven waar veel met de computer wordt gewerkt, zal het risico groter zijn. Voor een effectieve aanpak van RSI 
is het van belang om te weten in welke sectoren WAOintrede door RSI het meest voorkomt. Daarmee komen we op de volgende vraagstellingen:

\section{Zijn er veranderingen in de WAO-instroom door RSI} in de periode $1998 \mathrm{t} / \mathrm{m} 2004$ ?

2. Zijn er risicosectoren te onderscheiden voor RSI?

3. Zijn er verschillen tussen mannen en vrouwen en tussen verschillende leeftijdsgroepen in de WAOinstroom door RSI?

Er is een discussie ontstaan over de naamgeving RSI. Er is namelijk lang niet altijd sprake van 'letsel' zoals de naam, Repetitive Strain Injuries, suggereert. Er gaan dan ook geluiden op om de term niet meer te gebruiken en te spreken van klachten van arm, nek of schouder, eventueel afgekort als CANS. Ook ligt de diagnose RSI vaak gevoelig. RSI wordt gezien als een hype en daarom niet als reden om een WAO-uitkering toe te kennen. Deze gevoeligheden kunnen op verschillende niveaus spelen, maar zullen artsen zeker beïnvloeden in hun toekenning van een diagnose. Omdat de term RSI nog steeds het meest gangbaar is, zal deze in dit artikel wel gebruikt worden. Met RSI bedoelen we zowel aspecifieke als specifieke aandoeningen van nek, schouder, arm en hand.

\section{METHODE}

Populatie

De gegevens die gebruikt zijn om deze vraagstellingen te beantwoorden, zijn afkomstig van UWV, de instantie die de gegevens over de WAO-uitkeringen beheert. Elke nieuwe uitkering is in het bestand voorzien van een door een verzekeringsarts bepaalde diagnosecode. UWV heeft over de jaren 1998 t/m 2004 gegevens ter beschikking gesteld over het aantal nieuwe WAO-uitkeringen met een diagnosecode die op RSI duidt, het totale aantal verzekerden en het totale aantal nieuwe WAOuitkeringen, uitgesplitst naar leeftijd, geslacht en bedrijfssector. Deze gegevens omvatten vrijwel de gehele Nederlandse beroepsbevolking, met uitzondering van zelfstandigen.

\section{Operationalisatie RSI}

Diagnoses worden gecodeerd volgens het CAS-codesysteem. Binnen dit systeem kunnen expliciet codes voor RSI onderscheiden worden. Er zijn echter aandoeningen met andere diagnosecodes die over het algemeen ook als RSI beschouwd worden. Er is daarom voor gekozen om onderscheid te maken in een nauwe en een ruimere definitie van RSI, hier te onderscheiden als RSI1 en RSI2.
Onder RSI2 vallen zowel aandoeningen die als aspecifieke RSI worden aangeduid (zoals L100, aspecifieke nekpijn) als aandoeningen die als specifieke RSI worden aangeduid (zoals N613, carpaletunnelsyndroom). De diagnosecodes worden weergegeven in tabel 1 . In de resultaten van dit onderzoek zal voornamelijk de bredere definitie van RSI beschreven worden. Wanneer de onderzoeksresultaten met de nauwe RSI-definitie duidelijk afwijken van de gehanteerde, brede RSI-definitie wordt dit in de tekst vermeld.

\section{Onafhankelijke variabelen}

De gegevens zijn opgesplitst naar geslacht, leeftijd en bedrijfssector. Leeftijd is opgedeeld in vijf categorieën, namelijk: jonger dan $25,25-35,35-45,45-55$ en 55 jaar en ouder. Om onderscheid te kunnen maken tussen bedrijfssectoren is de UWV-indeling naar sectoren aangehouden. Deze indeling is bij wet geregeld in de zogenoemde 'Regeling indeling bedrijfs- en beroepsleven in sectoren'. Er wordt hier niet gerapporteerd over sectoren met minder dan 10.000 werkzame personen, omdat de toevalsfactor te hoog zou worden bij een lage incidentie. Omdat er dan nog zeer veel sectoren overblijven zijn de sectoren tevens ingedeeld in vijf ongeveer even grote groepen, namelijk industrie/bouwnijverheid, voornamelijk kantoorwerk, handel, gezondheidszorg en overig. Deze groepen zullen in het hiernavolgende 'bedrijfstakken' worden genoemd.

| In de jaren 1998 t/m 2001 is de WAO-intrede door RSI flink gestegen, gevolgd door een sterke daling in $2002 \mathrm{t} / \mathrm{m} 2004$.

Tabel 1 Codes voor RSI in het CAS-codesysteem RSI definitie 1

L684: RSI van schouder/bovenarm

L685: RSI van elleboog/onderarm

L686: RSI van pols/hand

RSI definitie 2

bovenstaande plus:

| L100: aspecifieke nekpijn

L121: pijn in bovenste extremiteiten

L620: discopathie

L624: cervicobrachiaal syndroom

L643: artrose eerste carpometacarpale gewricht

C650: syndroom van Raynaud

L680: chron. crep. synovitis van hand/pols

L690: adhesieve capsulitis schouder

L694: epicondylitis lateralis

L695: epicondylitis medialis

N613: carpaletunnelsyndroom 
Bij vrouwen, bij personen in de leeftijdsgroep van 45-55 jaar en bij werknemers in de industrie en bouw komt de meeste WAO-intrede door RSI voor.

In sectoren waar veel computerwerk wordt verricht, is geen hogere WAO-intrede door RSI.

Gezien het hoge aantal werknemers en het hoge relatief risico in deze sectoren zouden maatregelen binnen uitzendbedrijven, reinigingsbedrijven en bouwbedrijven het meest effectief zijn om de totale WAO-intrede door RSI te doen dalen.

\section{Analyses}

Om de WAO-intrede door RSI in kaart te brengen zijn zowel incidentiecijfers als de proportie van RSI in de WAO berekend. De incidentiecijfers van WAO-intrede zijn berekend door per jaar het aantal werknemers dat met een diagnosecode RSI in de WAO terecht is gekomen te delen door de totale werkende populatie. Onder proportie verstaan we het jaarlijkse aandeel van RSI in de totale arbeidsongeschiktheidsinstroom; dat wil zeggen het aantal werknemers met RSI gedeeld door het totaal aantal werknemers dat in de WAO terecht is gekomen. Incidentiecijfers en proporties van de brede RSI-definitie zijn ook per subgroep berekend (leeftijd, geslacht en bedrijfstak). Omdat het verloop van de incidentie in grote mate wordt beïnvloed door de totale WAO-intrede, en deze na 2001 drastisch is gedaald, zullen vooral de proporties worden gepresenteerd.

Vanwege het grote aantal bedrijfssectoren en de vaak kleine aantallen per sector is het niet mogelijk om de proportie en incidentie per sector en per jaar te presenteren. Omdat het toch belangrijk is om inzicht te krijgen in risicosectoren is, per sector, het relatief risico berekend door de gemiddelde incidentie in de sector over de periode $1998 \mathrm{t} / \mathrm{m} 2004$ te delen door de totale gemiddelde incidentie. Tevens is het attributieve risico berekend, dat wil zeggen het percentage van alle WAO-intredes door RSI dat is toe te schrijven aan het werkzaam zijn in een bepaalde sector. ${ }^{5}$ In deze maat wordt zowel de hoogte van het risico in de sector als de omvang van die sector meegenomen.

\section{RESULTATEN}

Omvang WAO-intrede door RSI

In tabel 2 is de omvang van de WAO-intrede door RSI weergegeven. Uit de tabel blijkt dat er een stijging is opgetreden in de jaren $1998 \mathrm{t} / \mathrm{m}$ 2001, gevolgd door een daling in de jaren $2002 \mathrm{t} / \mathrm{m}$ 2004. De daling na $2001 \mathrm{kan}$ deels verklaard worden door de algehele daling van de WAO-intrede. In 2001 kwamen er nog ruim 100.000 werknemers in de WAO terecht, terwijl dit aantal in 2004 nog geen 60.000 bedroeg. De proportionele cijfers laten echter zien dat de WAO-intrede door RSI ook relatief gezien gedaald is.

\section{Verdeling naar geslacht}

In figuur 1 is de trendlijn weergegeven voor de proportie van RSI in de totale WAO-intrede, voor vrouwen en mannen apart. Uit de figuur blijkt dat deze proportie in 1998 nog vrijwel gelijk ligt, maar sinds 1999 bij vrouwen hoger is dan bij mannen. Bij zowel mannen als vrouwen stijgt de proportie tot 2001 , bij mannen van 2,8 naar $4,7 \%$, en bij vrouwen van 2,7 naar $7,0 \%$. Na 2001 daalt de proportie tot respectievelijk 3,5 (mannen) en 4,5\% (vrouwen).

\section{Verdeling naar leeftijdsgroep}

In figuur 2 is de proportionele WAO-intrede door RSI weergegeven voor de verschillende leeftijdsgroepen. Voor alle leeftijdsgroepen is een stijging te zien tot 2001

Tabel 2 Omvang WAO-intrede door RSI in $1998 \mathrm{t} / \mathrm{m} 2004$

\begin{tabular}{|c|c|c|c|c|c|c|c|}
\hline & 1998 & 1999 & 2000 & 2001 & 2002 & 2003 & 2004 \\
\hline Verzekerde personen & 6.509 .486 & 6.666 .737 & 6.730 .277 & 6.894 .537 & 6.877 .979 & 6.930 .873 & 6.880 .060 \\
\hline Totale WAO-intrede & 99.854 & 88.846 & 98.040 & 102.386 & 90.782 & 66.335 & 59.167 \\
\hline \multicolumn{8}{|c|}{ WAO-intrede door RSI: } \\
\hline RSI1 & 490 & 947 & 1.384 & 2.008 & 1.375 & 652 & 434 \\
\hline RSI2 & 2.648 & 4.123 & 5.126 & 6.112 & 5.149 & 3.059 & 2.381 \\
\hline \multicolumn{8}{|c|}{$\begin{array}{l}\text { Percentage RSI op werkzame personen } \\
\quad \text { (incidentie) }\end{array}$} \\
\hline RSI1 & $0,01 \%$ & $0,01 \%$ & $0,02 \%$ & $0,03 \%$ & $0,02 \%$ & $0,01 \%$ & $0,01 \%$ \\
\hline RSI2 & $0,04 \%$ & $0,06 \%$ & $0,08 \%$ & $0,09 \%$ & $0,07 \%$ & $0,04 \%$ & $0,03 \%$ \\
\hline \multicolumn{8}{|c|}{ Aandeel RSI in WAO (proportie): } \\
\hline RSI1 & $0,5 \%$ & $1,1 \%$ & $1,4 \%$ & $2,0 \%$ & $1,5 \%$ & $1,0 \%$ & $0,7 \%$ \\
\hline RSI2 & $2,7 \%$ & $4,6 \%$ & $5,2 \%$ & $6,0 \%$ & $5,7 \%$ & $4,6 \%$ & $4,0 \%$ \\
\hline
\end{tabular}




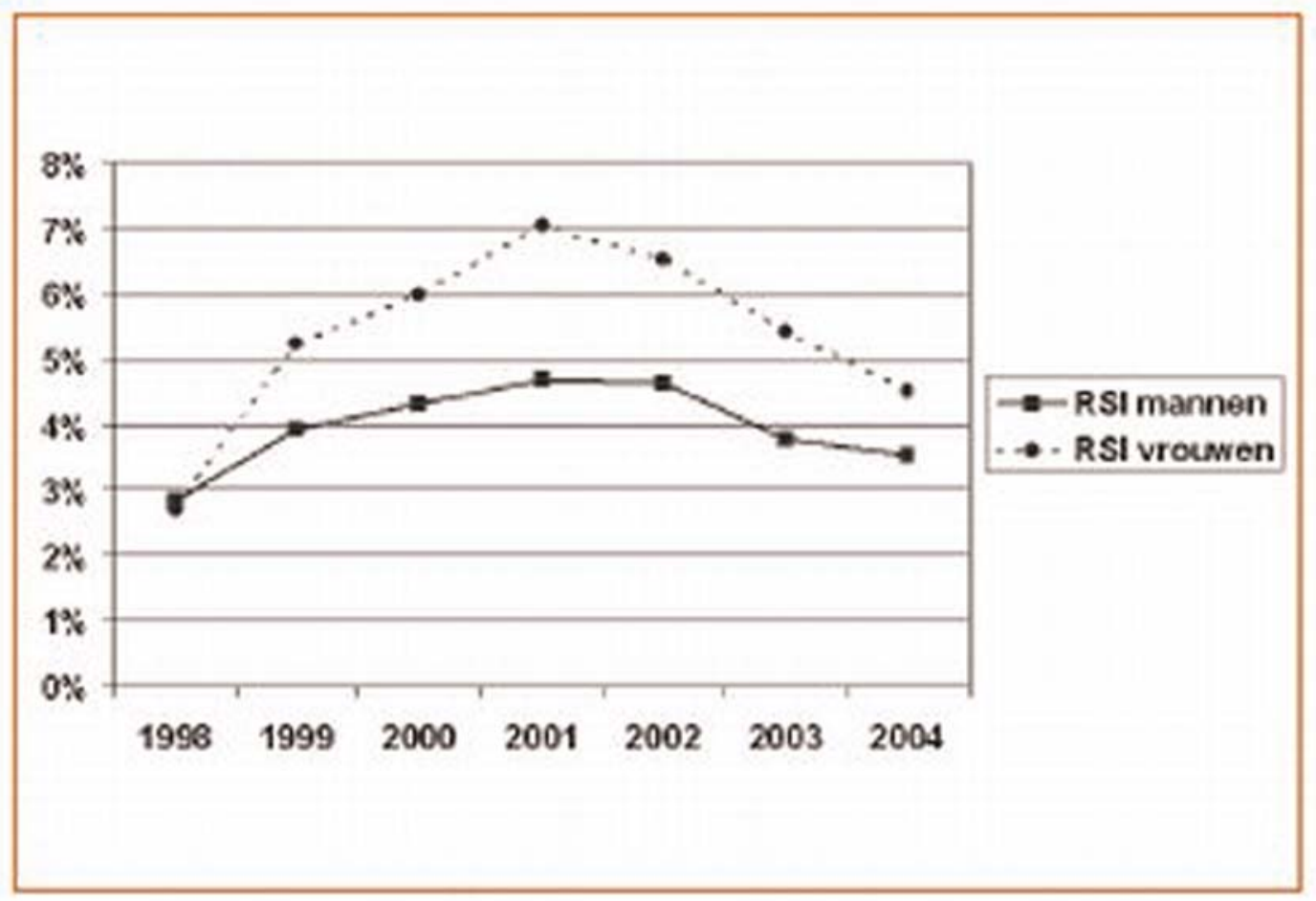

Figuur 1 Trendlijn proportie RSI in de totale WAO

of 2002, gevolgd door een daling. De proportie neemt toe met de leeftijd, met uitzondering van de groep die ouder is dan 55 jaar, waar de proportie van RSI juist relatief laag is. In 2002 was het proportionele percentage RSI in de WAO voor de groep jonger dan 25 jaar 3\%, voor de groep $25-35$ jaar $5,1 \%$, voor de groep $35-45$ en $45-55$ jaar $6,3 \%$, en voor de groep van 55 jaar en ouder $4,6 \%$. In 2004 waren deze percentage gedaald tot $1,5 \%$ (jonger dan 25), 3,1\% (25-35 jaar), 4,4\% (35-45 jaar), 4,7\% (4555 jaar) en $3,7 \%(55+)$.

Het relatief lage proportionele percentage RSI van de leeftijdsgroep van 55 jaar en ouder zou verband kunnen houden met concurrerende diagnoses. De totale WAOintrede is namelijk relatief hoog in deze groep. In dat geval kunnen de incidentiecijfers meer inzicht verschaffen. Hieruit blijkt dat de groep van 55 jaar en ouder weliswaar een lagere incidentie heeft dan de groep 45-55-jarigen, maar dat de incidentie vergeleken met de andere leeftijdsgroepen wel hoog is. In 2001, wanneer de incidentie voor alle leeftijdsgroepen op zijn hoogst is, zijn de incidentiecijfers voor RSI voor 55 jarigen $0,12 \%$, voor $45-55$-jarigen $0,10 \%$, voor $35-45$-jarigen $0,09 \%$, voor $25-35$-jarigen $0,05 \%$ en voor de groep jonger dan 25 jaar $0,01 \%$.

Verdeling naar bedrijfstak

In figuur 3 is weergegeven hoe de proportie van RSI in de WAO-intrede zich ontwikkelt in de vijf eerder gedefinieerde bedrijfstakken. In de industrie is de RSIproportie over alle jaren heen het hoogst. In de branches waar men zich voornamelijk met kantoorwerk bezighoudt, is de RSI-proportie over de meeste jaren ongeveer gemiddeld, maar wel is er duidelijker dan in de andere bedrijfstakken, een piek te zien in 2001. De RSI-proportie in de gezondheidszorg is ongeveer gemiddeld, maar was in 1998 extreem laag. Wanneer alleen gekeken zou worden naar de nauwe RSI-definitie is de RSI-proportie het hoogst in de sectoren waar voornamelijk kantoorpersoneel werkt (resultaten niet weergegeven).

\section{Verdeling naar sector}

In tabel 3 zijn de resultaten per sector weergegeven. De volgorde is gebaseerd op de hoogte van het gemiddelde relatieve risico over de gehele onderzoeksperiode, waarbij de sector met het hoogste relatieve risico het eerste genoemd wordt. Er kan geen attributief worden berekend in sectoren met een verlaagd risico.

Drie sectoren uit de voedingsmiddelenbranche blijken het hoogste relatieve risico voor WAO-intrede door RSI te hebben. Deze sectoren blijken ook een hoog relatief risico te hebben wanneer alleen de nauwe RSI-definitie wordt gehanteerd, maar het hoogste relatief risico wordt dan gevonden bij de uitgeverijen (resultaten niet weergegeven). Uitzendbedrijven en Reinigingsbedrijven hebben het hoogste attributief risico, gevolgd door de sector 


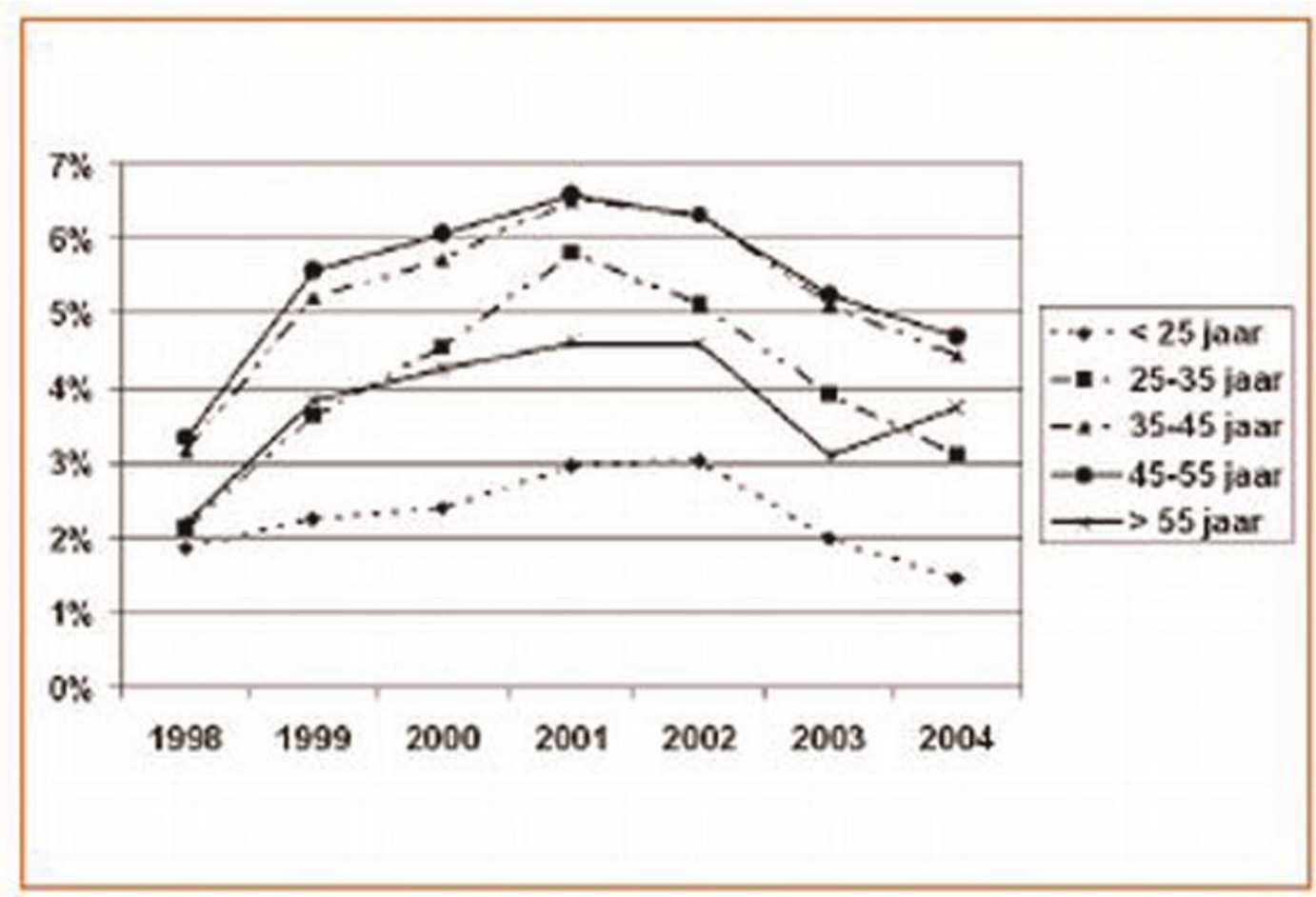

Figuur 2 Trendlijn proportie RSI in de totale WAO-intrede; voor mannen en vrouwen apart intrede; voor verschillende leeftijdsgroepen

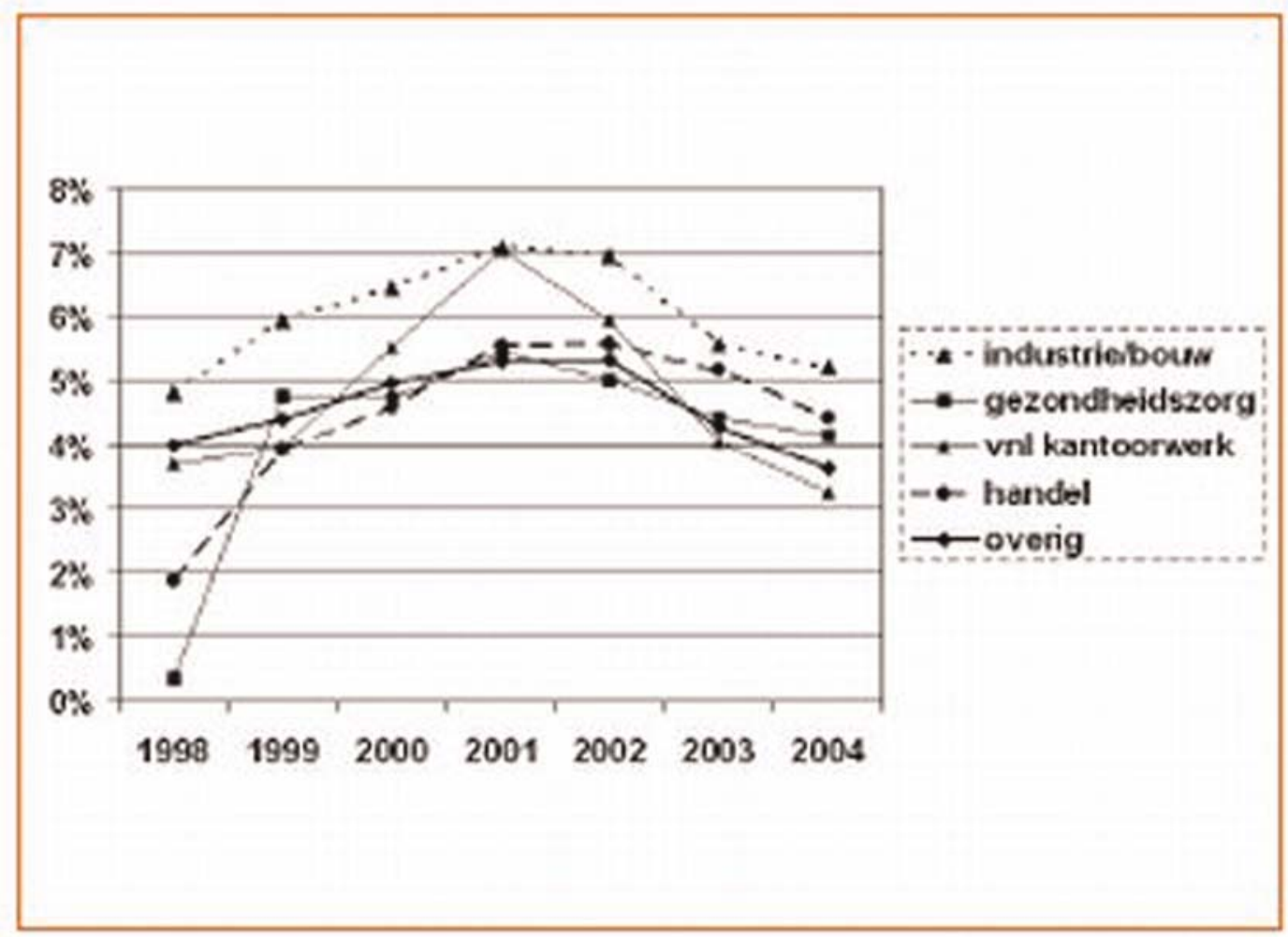

Figuur 3 Trendlijn RSI voor verschillende bedrijfstakken

Bouwbedrijf. Het aantal verzekerde personen in deze sectoren (gemiddeld over de periode $1998 \mathrm{t} / \mathrm{m}$ 2004) is ook relatief hoog, wat een belangrijke factor is voor de bepaling van het attributieve risico. De sector Uitzendbedrijven bijvoorbeeld telde gemiddeld ruim 300.000 verzekerde personen. De sector met het hoogste relatieve 
Tabel 3 Gemiddelde relatief risico en attributief risico van RSI per sector in aflopende volgorde

\begin{tabular}{|c|c|c|}
\hline & $\begin{array}{r}\text { Relatief } \\
\text { risico }\end{array}$ & $\begin{array}{r}\text { Attributief } \\
\text { risico }\end{array}$ \\
\hline Horeca catering & 3,30 & 0,19 \\
\hline Suikerverwerkende industrie & 2,96 & 0,13 \\
\hline $\begin{array}{l}\text { Slagers overig (vlees- en } \\
\text { vleeswarenindustrie) }\end{array}$ & 2,84 & 0,24 \\
\hline Textielindustrie & 2,35 & 0,10 \\
\hline Reiniging & 2,14 & 1,20 \\
\hline Schildersbedrijf & 2,00 & 0,21 \\
\hline Openbaar vervoer & 1,86 & 0,07 \\
\hline $\begin{array}{l}\text { Steen-, cement-, glas- en keramische } \\
\text { industrie }\end{array}$ & 1,73 & 0,17 \\
\hline Overige takken van bedrijf en beroep & 1,66 & 0,25 \\
\hline Uitzendbedrijven & 1,65 & 1,80 \\
\hline $\begin{array}{l}\text { Algemene industrie (papier, rubber, } \\
\text { geneesmiddelen, delfstoffen, kleding, } \\
\text { leer) }\end{array}$ & 1,64 & 0,36 \\
\hline Elektrotechnische industrie & 1,60 & 0,35 \\
\hline Uitgeverij & 1,55 & 0,20 \\
\hline Vervoer Posterijen & 1,53 & 0,39 \\
\hline Bouwbedrijf & 1,48 & 0,94 \\
\hline Meubel- en orgelbouwindustrie & 1,44 & 0,10 \\
\hline Voedingsindustrie & 1,35 & 0,24 \\
\hline Grafische industrie & 1,30 & 0,18 \\
\hline Metaalindustrie & 1,27 & 0,47 \\
\hline Voormalige sector overheidsdiensten & 1,27 & 0,30 \\
\hline Chemische industrie & 1,26 & 0,26 \\
\hline Telecommunicatie & 1,23 & 0,11 \\
\hline Zuivelindustrie & 1,17 & 0,02 \\
\hline Vervoer KLM & 1,14 & 0,05 \\
\hline Timmerindustrie & 1,08 & 0,01 \\
\hline Overheid, overige instellingen & 1,04 & 0,02 \\
\hline $\begin{array}{l}\text { Gezondheid, geestelijke en } \\
\text { maatschappelijke belangen }\end{array}$ & 1,03 & 0,44 \\
\hline Verzekeringswezen en ziekenfondsen & 0,99 & \\
\hline Slagersbedrijven & 0,98 & \\
\hline Havenbedrijven & 0,98 & \\
\hline Grootwinkelbedrijf & 0,95 & \\
\hline Metaal- en technische bedrijfstakken & 0,91 & \\
\hline $\begin{array}{l}\text { Overig goederenvervoer te land en in de } \\
\text { lucht }\end{array}$ & 0,90 & \\
\hline Bakkerijen & 0,90 & \\
\hline Groothandel II & 0,90 & \\
\hline Taxi- en ambulancevervoer & 0,87 & \\
\hline Zakelijke dienstverlening I & 0,86 & \\
\hline $\begin{array}{l}\text { Overheid, provincies, gemeenten en } \\
\text { waterschappen }\end{array}$ & 0,85 & \\
\hline Agrarisch bedrijf & 0,85 & \\
\hline Vervoer NS & 0,84 & \\
\hline Zakelijke dienstverlening III & 0,83 & \\
\hline Culturele instellingen & 0,83 & \\
\hline
\end{tabular}

Tabel 3 (continued)

\begin{tabular}{lrr}
\hline & $\begin{array}{r}\text { Relatief } \\
\text { risico }\end{array}$ & $\begin{array}{r}\text { Attributief } \\
\text { risico }\end{array}$ \\
\hline Overheid, openbare nutsbedrijven & 0,81 & \\
Banken & 0,79 & \\
Werk en (re)integratie & 0,77 & \\
Zakelijke dienstverlening II & 0,74 \\
Detailhandel en ambachten & 0,73 \\
Overheid, rijk, politie en rechterlijke & 0,63 \\
$\quad$ macht & & \\
Groothandel I & 0,61 \\
Horeca algemeen & 0,51 & \\
Overheid, onderwijs en wetenschappen & 0,43 \\
Bewakingsondernemingen & 0,42 \\
Overheid, defensie & 0,17 \\
\hline
\end{tabular}

risico, Horeca Catering, telde nog geen 18.000 verzekerde personen. Wanneer alleen naar de nauwe RSI-definitie wordt gekeken wordt het hoogste attributief risico gevonden in de sector Gezondheidszorg en de sectoren Zakelijke Dienstverlening II en III.

\section{DISCUSSIE EN CONCLUSIES}

In absolute aantallen is de WAO-intrede door RSI van 1998 tot 2001 explosief gestegen. Dit geldt voor vrijwel alle leeftijdsgroepen, met uitzondering van de groep jonger dan 25 jaar. Bij vrouwen is er sprake van een grotere stijging dan bij mannen. Na 2001 daalt de incidentie van WAO-intrede door RSI weer, om in 2004 ongeveer op het niveau van 1998 uit te komen. Dit is deels te verklaren door de algehele daling van de WAO-intrede. De proportionele cijfers laten echter zien dat het aandeel van RSI in de WAO-intrede ook voor 2001 gestegen en daarna gedaald is, zij het in mindere mate.

Er zijn nog geen cijfers over prevalentie van klachten bekend die een beeld geven van de jaren 2003 en 2004. Uit eerder onderzoek van Heinrich en Blatter naar de prevalentie van RSI-klachten tussen 2000 en 2002 blijkt dat niet alleen de WAO-intrede, maar ook de prevalentie van RSI-klachten bij vrouwen hoger is en harder is gestegen dan bij mannen. ${ }^{1}$ Een hogere prevalentie en WAOintrede bij vrouwen kan zowel te maken hebben met een verschil in arbeidsomstandigheden als met een verschil in belastbaarheid. Een stijging van zowel klachten als WAO-intrede zou mogelijk onder meer verband kunnen houden met een toename aan beeldschermwerk en aan minder gevarieerd werk bij vrouwen. ${ }^{1}$

Prevalentie van klachten en incidentie van WAOintrede blijken ook overeen te komen met betrekking tot de trend over verschillende leeftijdsgroepen. Een 
uitzondering vormt de leeftijdsgroep van 20-25 jaar. Uit het eerdergenoemde onderzoek van Heinrich en Blatter, blijkt dat klachten het meest toegenomen zijn in deze leeftijdsgroep, ${ }^{1}$ terwijl de incidentie van WAO-intrede door RSI bij de jongeren juist vrij constant is gebleven. Er is geen duidelijke verklaring voor dit verschijnsel. Wel kan opgemerkt worden dat de WAO-intrede door jongeren in het algemeen al erg laag is en WAO-intrede door RSI zeer weinig voorkomt in deze groep, waardoor de toevalsfactor groot is. Opvallend is dat in de UWV-sectoren met een hoog relatief risico niet veel computerwerk wordt gedaan, terwijl RSI daar toch vooral mee geassocieerd wordt. De UWV-sectoren met het hoogste relatieve risico komen uit de voedingsmiddelenindustrie, namelijk cateringbedrijven, vee- en vleeswarenindustrie en suikerverwerkende industrie, gevolgd door de textielindustrie en reinigingsbedrijven. Dit is niet verbazend, aangezien er in deze sectoren veel repeterend, zwaar werk met de handen en armen wordt verricht. Er zijn geen gedetailleerde recente cijfers bekend over risicosectoren in Nederland voor wat betreft prevalentie van RSIklachten. Wel is in het onderzoek van Heinrich en Blatter naar beroepsgroepen gekeken. Op het eerste gezicht lijken de bevindingen van dit onderzoek echter niet in overeenstemming met de cijfers over UWV-sectoren met een hoog risico. De beroepsgroepen voedingsmiddelenbereiders, kleermakers en schoonmakers uiten niet significant meer klachten dan gemiddeld. ${ }^{1}$ Voor wat betreft de voedingsmiddelenbereiders kan dit te maken hebben met het feit dat zij niet allemaal werkzaam zijn in UWV-sectoren met een hoog relatief risico. De UWVsectoren 'voedingsindustrie', 'horeca algemeen' en 'bakkerijen' hebben een beduidend lager relatief risico. Kleermakers zullen waarschijnlijk wel allen afkomstig zijn uit de UWV-sector 'textiel-industrie'. Dat kleermakers in het genoemde onderzoek niet zijn geïdentificeerd als beroepscategorie met relatief veel RSI-klachten kan op toeval gebaseerd zijn, aangezien de textielindustrie een kleine sector is ( \pm 12.000 werknemers). Het is onduidelijk waarom het schoonmaakpersoneel niet als risicogroep geïdentificeerd werd in genoemd onderzoek. Wanneer een keuze gemaakt moet worden voor bedrijfstakken met een hoog risico, met als doel de WAO-intrede door RSI zoveel mogelijk te verminderen is het goed om te kijken naar het attributieve risico. Er zullen dan meer werknemers bereikt worden die zich in een risicosituatie bevinden. Uitschieters op het gebied van een hoog attributief risico zijn de uitzendbedrijven, de reinigingsbedrijven en de bouwbedrijven.

De daling van het relatieve aantal werknemers dat met de diagnose RSI in de WAO terechtkomt, zou verband kunnen houden met de stijgende aandacht voor de problematiek vanaf circa 1999. In dat jaar is een voorlichtingscampagne van het ministerie van Sociale Zaken en Werkgelegenheid gestart. Was deze vooral gericht op gedragsaanpassing van de individuele beeldschermwerkers, ook industriële ontwerpers en softwareontwikkelaars onderkenden het probleem steeds meer, waardoor diverse producten op de markt kwamen, zoals ergonomische toetsenborden, alternatieve muismatjes en pauzesoftware. Binnen bedrijven kwam ook meer aandacht voor het probleem en werden maatregelen genomen, vooral in de bedrijfssectoren waar veel beeldschermwerk werd verricht ${ }^{6}$

Een ander voorbeeld zijn de arboconvenantentrajecten die bij enkele branches zijn afgesloten en die RSI als aandachtspunt hebben. Al deze ontwikkelingen kunnen ervoor gezorgd hebben dat de toename van de WAOintrede door RSI is gestopt. Dat de meeste aandacht uitgaat naar beeldschermwerkers lijkt weerspiegeld in de duidelijkere daling bij branches waar voornamelijk kantoorwerkzaamheden worden uitgevoerd.

Daarnaast dienen we ons ook te realiseren dat een daling van de WAO-intrede in het algemeen en van de WAO-intrede door RSI in het bijzonder, een afspiegeling kan zijn van een strengere keuringspraktijk. In 2002 is in het SER-advies gepleit voor scherpere hantering van het duurzaamheidscriterium. Sinds 2002 is de WAO-intrede gedaald van ruim 90.000 in 2002 tot nog geen 60.000 in 2004. Hoewel het niet helemaal duidelijk is of deze afname geheel op het conto van deze politieke ontwikkelingen zijn te schrijven lijkt het de keuringspraktijk van de verzekeringsartsen behoorlijk te hebben beïnvloed. Ten slotte kan het economische klimaat in Nederland van invloed zijn geweest op de WAO-intrede. Ten tijde van een economische depressie heerst er veel onzekerheid over de perspectieven op de arbeidsmarkt. Mogelijkerwijs is tegelijkertijd de werkdruk minder hoog dan in tijden van economische groei. Dit verschijnsel zou er aan hebben kunnen bijdragen dat de WAO-intrede door RSI gedaald is.

Zoals al eerder is aangegeven is in dit onderzoek gekozen voor een ruime definitie van RSI. Wanneer alleen gekeken wordt naar de nauwe RSI-definitie komen andere risicosectoren in beeld, namelijk sectoren waar veel kantoorwerk wordt uitgevoerd, zoals de zakelijke dienstverlening. Dat is niet verwonderlijk, omdat RSI toch vooral met beeldschermwerk geassocieerd wordt. Dat zal ook in de praktijk van de verzekeringsgeneeskunde het geval zijn. Wanneer RSI gezien wordt als specifieke en aspecifieke klachten aan arm, nek of schouders, blijkt dat echter niet terecht te zijn.

Belangenconflicten: geen gemeldFinanciële ondersteuning: ministerie van SZW 


\section{LITERATUUR}

Heinrich J, Blatter BM. RSI-klachten in de Nederlandse beroepsbevolking. Trends, risicofactoren en verklaringen. Tijdschr Soc Geneeskd 2005; 83: 16-24.

Blatter BM, Heuvel SG van den, Bongers PM, et al. De omvang van verzuim en arbeidsongeschiktheid door RSI. Den Haag: ministerie van SZW, 2001.

Gezondheidsraad. RSI. Den Haag: Gezondheidsraad, 2000, publicatie nr 2000/22.
Bongers PM, Kremer AM, Laak J ter. Are psychosocial work characteristics, risk factors for symptoms and signs of the shoulder, elbow, or hand/wrist?: A review of the epidemiological literature. Am J Ind Med 2002; 41: 315-342.

Rothman KJ. Modern Epidemiology. Boston: Little, Brown and Company, 1986, p. 39.

Bossche SNJ van den, Smulders PGW. De Nationale Enquête Arbeidsomstandigheden 2003; Methodologie en globale resultaten. Hoofddorp: TNO Arbeid, 2004. 